\title{
論文
}

\section{ランクオーダフィルタによるカラーテレビ信号中の インパルス性雑音の除去}

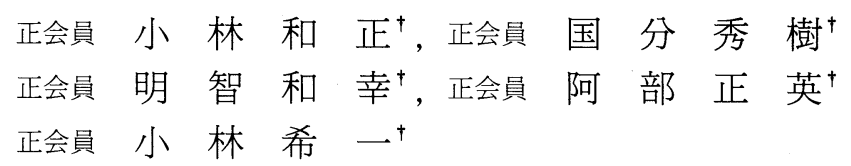

\section{Impulse Noise Elimination in NTSC Color Television Signals Using Rank-Order Filters}

\author{
Kazumasa Kobayashi ${ }^{\dagger}$, Hideki Kokubun ${ }^{\dagger}$, Kazuyuki Akechi ${ }^{\dagger}$, \\ Masahide $\mathrm{Abe}^{\dagger}$ and Ki-ichi Kobayashi ${ }^{\dagger}$
}

\begin{abstract}
In this paper, a Rank-Order Filter(ROF) and its application to TV signals are discussed. In order to apply ROF to eliminate impulse noise from NTSC color TV signals, we propose: a) kernal structure suitable for NTSC composite signals; b) theoretical analysis of ROF noise elimination characteristics; c) subjective evaluation method for noise elimination from realtime TV signals. In addition, an experimental noise elimination setup and experimental results of subjective evaluation using ROF LSIs we have developed is described. Finally, it is confirmed that ( a ) it is effective for NTSC composite signals to employ a kernel in a temporal direction where signals of the same phase color-subcarrier can be sampled and that $(b)$ the results of subjective evaluation are consistent with the calculated results of theoretical analysis.
\end{abstract}

\section{1. ま え がき}

テレビ信号には, 様々な原因によってインパルス性 の雑音が混入する場合がある. 濃淡画像処理の分野で は, この種の雑音(以下本論文では特に断わらない場 合，インパルス性の雑音を単に雑音と呼ぶ）を効果的 に除去する非線形フィルタとして, メディアンフィル タやランクオーダフィルタ1) (メディアンフィルタを 包含する, より広い非線形フィル夕の一種であり，処 理領域内の画素の中から，信号レベルに関して任意の 順位を有する画素の信号を選択して出力とするフィル
夕）が提案されている.しかし従来, カラーテレビ信 号中の雑音除去にこの種のフィルタの適用が検討され た例はほとんどなかった。

そこで本論文では, カラーテレビ (NTSC コンポジ ット）静止画像中に混入したインパルス性雑音を除去 するためのランクオーダフィルタの構成法について検 討し, その雑音除去効果の評価法を提案する. そのた め, まず 2 章においてランクオーダフィル夕を効果的 に適用するための処理領域（以下カーネルと呼ぶ）形 状について考察する. 次に 3 章において, 著者らが行 ったランクオーダフィルタの雑音除去特性の定式化 ${ }^{2)}$

キーワード：ランクオーダフィルタ, インパルス性雑音, 雑音除去, NTSC 信号

1990 年 3 月 18 日, 電子情報通信学会全国大会で発表

1989 年 10 月 20 日受付, 1990 年 3 月 22 日再受付

$\dagger$ NHK 放送技術研究所（于157 東京都世田谷区砧 1-10-11, TEL. 03-415-5111)

$\dagger$ NHK Science and Technical Research Laboratories (1-10-11, Kinuta, Setagaya-ku, Tokyo 157, Japan) 
を応用し, テレビ画像中に見られる, めだか状の雑音 に対するメディアンフィルタの雑音除去効果を客観的 に評価するための検討を行う．4 章では，著者らがこ れまでに開発した, 汎用的なランクオーダフィルタ $\mathrm{LSI}^{3) \sim 5)}$ (以下順序フィルタ LSI と呼ぶ）を用いた雑音 除去実験装置と, テレビ信号中のインパルス性雑音の 除去効果の主観的評価法について述べる．5 章では， 本論文で提案したランクオーダフィルタの構成と, 雑 音除去効果の評価法の妥当性について検証するととも に, これを動画像処理へ応用する場合の課題について 考察する.

\section{NTSC 信号に対するカーネル形状の検討}

ランクオーダフィルタは, カーネル内における任意 の順位（以下ランクという）に相当する画素の信号レ ベルを出力するものであり, 画素間の信号レベルの大 小関係に応じて画素信号を入れ替えるため, 空間周波 数の高い信号波形に著しい歪みを生じる場合がある. そのため, この種のフィルタの適用に当たっては, フ イルタの雑音除去の効果と, 逆にフィルタによって新 たに付加される歪みの程度を勘案する必要がある.

従来, 濃淡画像の処理に応用されることの多かった この種のフィルタについては, 処理対象とする画像に おける最も大きな画質劣化要因がインパルス性雑音に ある場合の画質改善のために使用される例が多く, 新 たな歪みの発生は大きな問題とされていなかった。一 方, 本論文で考察の対象とするカラーテレビ信号は, 以下の特徵を持っている.

第一に, テレビ信号を 1 つの濃淡画像信号として扱 った場合, 色信号が輝度信号の高域成分として周波数 多重されているため, 彩度の高い色を有するすべての 領域で致命的な歪みを生ずる可能性があること, 第二 に, 文字ダブリ部分などのような, 歪みの発生が全く 許容できない領域がかなりの時間率で発生すること, 第三に, テレビ信号の静止領域では, 時間（フィール ド）方向に相関の非常に高い画素が存在すること, 等 である. 特に, 第一, 第二の特徵から, 空間的に大き なカーネルを使うことは適当でない.

したがって, カラーテレビ信号に対して有効に作用 するランクオーダフィルタを構成するためには，でき るだけ歪みの発生が少なく, しかも効率良く雑音を除 去できるカーネルを見いだすことが重要である．この ような条件は, カーネル内の各画素のカラーサブキャ リヤの位相が揃うようにすることでほぼ満たされる。 例えば, $4 f_{s c}(14.3 \mathrm{MHz})$ で標本化された画像に対し て, 例えば図 1 に示す 3 種類のカーネルが考えられ
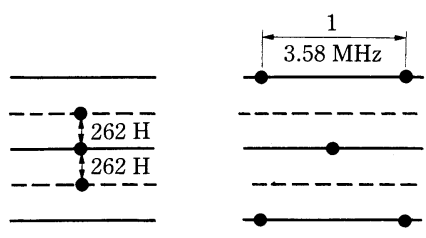

(a) フィールド間

(b) フィールド内 1

(c) フィールド内 2

図 1 NTSC コンポジット信号に対するカーネル構 造の例 ${ }^{6)}$

Examples of the Kernel structure for NTSC composite signal.

る。これらのカーネルの得失には 5 章で考察する.

\section{3. 雑音除去効果に関する理論的検討}

この章では，ランクオーダフィルタをテレビ信号中 の雑音除去に適用した場合に, フィルタの効果を解析 的に表現するための検討を行う.

テレビ信号に混入するインパルス性雑音として, 降 雨時等の BS 受信画像中に見られるような, めだか状 雑音の類がある。この種の雑音には

(1) 時間的にランダムに発生する.

(2) ほぼ一定の時間（画像中の水平方向に）持続す る(一例として, 我々が実験に使用した BS 受信 画像に現れるめだか状雑音の持続画素数は, 14.3 $\mathrm{MHz}$ で標本化された画像において 10 程度と観 察された)。

(3) 黒く見える雑音と白く見える雑音の比率が, 時 間の経過やチャンネルによって変動することがあ る。

等の特徴がある.上記(2)項は, 濃淡画像処理で通常想 定している単位インパルス性の雑音と, 実際のテレビ 信号に混入する雑音との大きな違いである．このため 以下の考察では, インパルス性雑音の発生確率と, こ の雑音が混入したことによって影響を受けた画素(以 下雑音画素と呼ぶ)の発生確率を区別して考える。ま た，雑音画素の中で画面上明るく見えるものを白雑音 画素, 暗く見えるものを黒雑音画素と呼ぶことにする.

著者らがすでに報告したように2)，入力画像におけ るインパルス性雑音の発生確率を $p$, 雑音画素全体の 中で白雑音画素の占める割合を $p_{w}$, 雑音の持続画素 数を $l, l$ の期待值を $E(l)$, カーネル内に含まれる画 素数を $W$ (簡単のため奇数とする), ランクオーダフ イルタのランクを $r$ (最大值に対して 1 , 最小值に対 して $W$ をとる正の整数とする）とし, また雑音画素 
の発生確率が $p \cdot E(l)$ で与えられるものとすると, ラ ンクオーダフィルタの出力に雑音画素が選択されない 確率 $P_{N L}$ (逆に $1-P_{N L}$ が雑音画素に選択される確率を 示す)は，メディアン(中間值)を出力として指定する ときのランクを $M(=(W+1) / 2)$ として

$$
\text { (i ) } \begin{aligned}
& r \leqq M \text { のを } \\
& P_{N L}= \sum_{n=0}^{r-1}{ }_{W} C_{n} \cdot(1-p \cdot E(l))^{W-n} \cdot(p \cdot E(l))^{n} \\
&+\sum_{n=r}^{W-1}{ }_{W} C_{n} \cdot(1-p \cdot E(l))^{W-n} \cdot(p \cdot E(l))^{n} \\
& \times \sum_{i=n-W+r}^{r-1}{ }_{n} C_{i} \cdot\left(1-p_{w}\right)^{n-i} \cdot p_{w}{ }^{i}
\end{aligned}
$$

(ii) $r>M$ のとき,

$$
\begin{aligned}
P_{N L}= & \sum_{n=0}^{W-r}{ }_{W} C_{n} \cdot(1-p \cdot E(l))^{W-n} \cdot(p \cdot E(l))^{n} \\
& +\sum_{n=W-r+1}^{W-1}{ }_{W} C_{n} \cdot(1-p \cdot E(l))^{W-n} \cdot(p \cdot E(l))^{n} \\
& \times \sum_{i=n-r+1}^{W-r}{ }_{n} C_{i} \cdot\left(1-p_{w}\right)^{i} \cdot p_{w}{ }^{n-i}
\end{aligned}
$$

となる. 例えば, 白雑音画素と黒雑音画素の現れる頻 度が同じ $\left(p_{w}=1 / 2\right)$ 場合の 3 タップのメディアンフィ ル夕に対する $P_{N L}$ は，（1）式に $r=2, W=3$ を代入す ることによって次式で表される。

$$
P_{N L}=1-\frac{3}{2}(p \cdot E(l))^{2}+\frac{1}{2}(p \cdot E(l))^{3}
$$

あらかじめ雑音画素の発生確率が測定されている場 合には，（1)式または（2)式から直接雑音除去特性を 求めることができる。しかしテレビ信号に混入する, 水平方向に相関を有する雑音に対して定量的な評価実 験を行う場合には, 雑音の発生確率と雑音の持続画素 数を制御する方が容易であるため, 本論文では 4 章以 下に扔いて, 雑音の発生確率と雑音の形状(長さ) に対 する情報から, 入力画像, 出力画像それぞれにおける 雑音画素の発生確率を推定し,これと（1)式または (2) 式とを比較することによって, 雑音除去特性を評 価することとした。

定性的な考察によれば, 雑音の発生確率 $p$ が増加 するにつれて, ある雑音が発生した後その雑音の持続 期間内に次の雑音が発生する機会が増加するため, 入 力に扔ける雑音画素の発生確率 $p \cdot E(l)$ の増分は $p$ の 増加とともに減少する傾向を持つと予想される。ここ で考察する雑音の場合，雑音の性質(2)で仮定したよう に雑音どうしの重なりがない場合の持続画素数 $l$ が一 定であるから, 重なりがある場合の雑音の持続画素数 を $x$ とすると, $x$ の確率分布 $P(x)$ は図 $\mathbf{2}$ に示す幾何 分布に従うと仮定できるため,

$$
P(x)=p \cdot(1-p)^{x-1}
$$

で表される。またこれを用いて $l$ 期待值 $E(l)$ は，

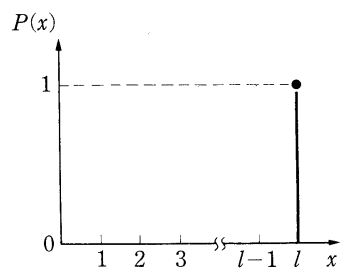

(a) $p^{-1} \gg l$ の時

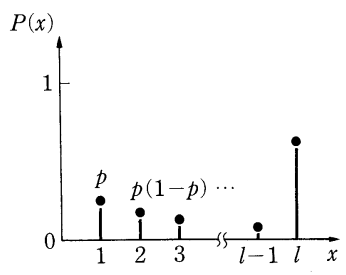

(b) $p^{-1} \leqq l$ の時
図 2 雑音の持続長さの確率分布

Probability distribution for the 'noise length'.

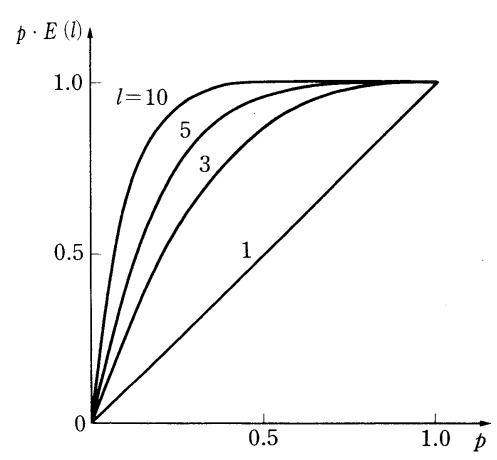

図 3 雑音画素の発生確率

Occurrence probability of the noise pixel.

$$
E(l)=\sum_{x=1}^{l-1} x \cdot P(x)+l \cdot\left\{1-\sum_{x=1}^{l-1} P(x)\right\}
$$

から計算でき，(4)式と(5)式から雑音画素の発生確 率 $p \cdot E(l)$ を求めることができる. $p$ と $p \cdot E(l)$ の関 係が $l$ と共に変化する様子を図 3 に示した。

\section{4. 雑音除去効果の主観的評価法}

\section{1 実験装置}

テレビ信号中の雑音除去におけるランクオーダフィ ルタの効果を検証し，かつ前章での理論的検討の妥当 性を確認する目的で，テレビ信号を混入するインパル ス性雑音の除去実験を行った。図 4 に雑音除去実験の 系統図を示す。信号源には, BSアンテナの IF 出力 $(1 \mathrm{GHz})$ に白色の雑音を混入して，これを BSチュー ナで復調した画像 (動面像. 以下, 信号源 A と呼ぶ) と, テレビカメラでテストパターンを撮像し，これに めだか状雑音を単純化した，ステップ状の人工的なイ ンパルス性雑音を付加した画像（静止画像．以下信号 源 B と呼ぶ）とを用いた．人工的な雑音を混入させる 場合, 雑音発生確率 $p$, 雑音画素中で白雑音画素の占 める割合 $p_{w}$, 雑音の持続画素数 $l$ を自由に変えられ るようにした。また，必要に応じて入力信号の形式と してNTSCコンポジット信号あるいは RGB コンポ 
ーネント信号を選択して使用できるようにした。

\section{2 雑音除去効果の主観評価実験}

信号源としてテレビ画像を用いている場合，雑音の 発生状況は時間的に変動する。そのため, フィル夕の 雑音除去効果を時々刻久定量的に求めることは, 現状 では困難である，そこで，以下の実験手順によって雑 音除去効果の定量化を試みた。

\section{評価実験の手順}

手順 (1)：まず信号源 B において, 雑音の発生確率 pを種々変えた入力信号のモニ夕上の像をスチル カメラで撮影し, これをかの小さい順に並べて 入力画像の系列を作る.

手順 (2)：ランクオーダフィルタによる処理画像に ついてもスチルカメラで撮影しておき，同様に出 力画像の系列を作る.

手順 (3)：このようにして得られた出力画像の系列 の中からランダムに 1 枚を抜き出し，これを被験 者に提示して, その雑音の現れ方が最も類似して いると判断される入力画像の系列の中の 1 枚を指 摘させる。このとき, 同時にフィル夕によって発 生する歪みは評価の対象とせず，画面内の雑音の 発生状況のみに着目して評価させる。

手順 (4) : 同様の操作を出力画像の系列に含まれる すべての写真について行う.

上記実験の結果得られる, 出力画像の等価的な（入 力画像中の雑音の混入状態との比較による）雑音画素 発生確率を, 入力画像の雑音画素発生確率 $p \cdot E(l)$ の 関数として表し,これによりフィル夕の雑音除去効果 を評価することとする。

\section{5. 実験結果と考察}

\section{1 カーネル形状とフィルタの特性}

2 章で述べたように, NTSC コンポジット信号に おいて利用可能なカーネルの形状は, 図 1 に示した 3 種にほぼ限定される．同図の各カーネルを用いた場合 の雑音除去の効果と, 逆にそのカーネルを用いること によって発生する歪みの両者について，それぞれ単独 に定量化しておくことは, 今後この種のフィル夕の適 用可能性を検討するうえで重要となる，そこで，まず 前章で述べた評価法により各カーネルの雑音除去の効 果を評価する実験を行った ${ }^{6)}$.この実験ではテレビ技 術者 10 人を被験者とし, 雑音は 10 画素分持続するイ ンパルスを回路的に発生し，これを時間的にランダム に付加した(信号源 B).

図 5 に評価結果を示す．図中の実線は，3章での考 察さら導かれる,メディアンフィルタの雑音除去特性 の理論值を, カーネルサイズ $W$ が 3 および 5 の場合 について示した．この図から, 単に雑音除去の効果の みに着目した場合, 図 1 ( a ) と ( c ) とは, どちらも 3 タップのメディアンフィルタであることから, ほとん ぞ同量の雑音除去効果を持ち, かつ理論值と比較的良 い一致を示すのに対し, 図 1 (b)のカーネルでは, そ の中に含む画素の数が最も多いため, 雑音除去の効果 が高く評価されているが, 理論值とのずれも大きい. これは, テレビ信号に抢いては雑音が画像の水平方向 に相関を有することが多いため, 図 1 ( b ) のように水 平方向にも広がりを持つカーネルを用いたメディアン フィルタは, 同じ画素数を有しかつカーネル内の雑音

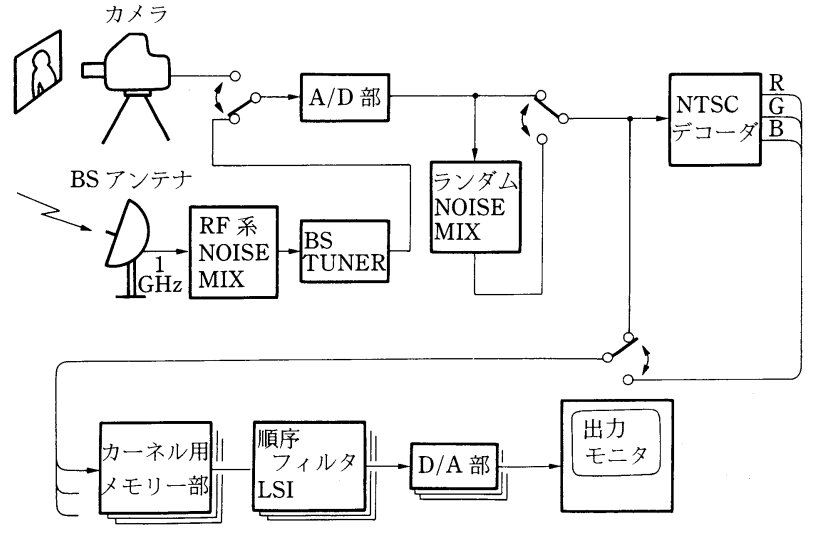

図 4 雑音除去実験の系統図 Block diagram of the experimental setup for the noise elmination.

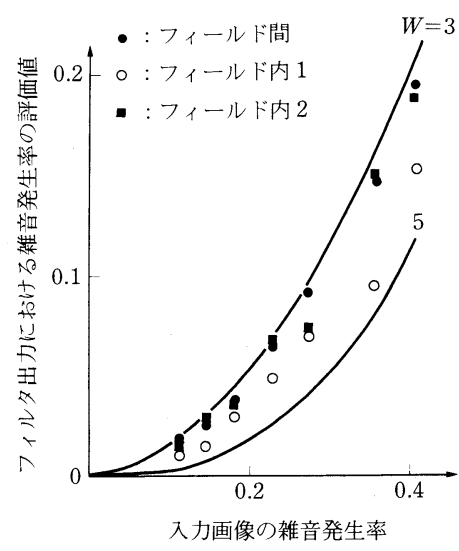

図 5 雑音除去効果の評価結果 ${ }^{6)}$ Experimental results in noise elimination using dedicated kernels.

論 文ロランクオーダフィルタによるカラーテレビ信号中のインパルス性雑音の除去

(135) 1093 
の発生が充分にランダムであると仮定できるカーネル （すなわち，画像の縦方向または時間方向に広がりを 持つカーネル)を用いたメディアンフィルタに比べて, 雑音除去の性能が低くなることによると考えられる.

次に, これらのカーネルによって新たに発生する歪 みの影響を 5 段階評定法で評価した。図 6 に ITEテ ストチャートに対する評価結果を示す。これにより， 図 1 (b), および( c) のカーネルでは静止画像に対し ても許容できないほどの歪みが発生し，そのままでは

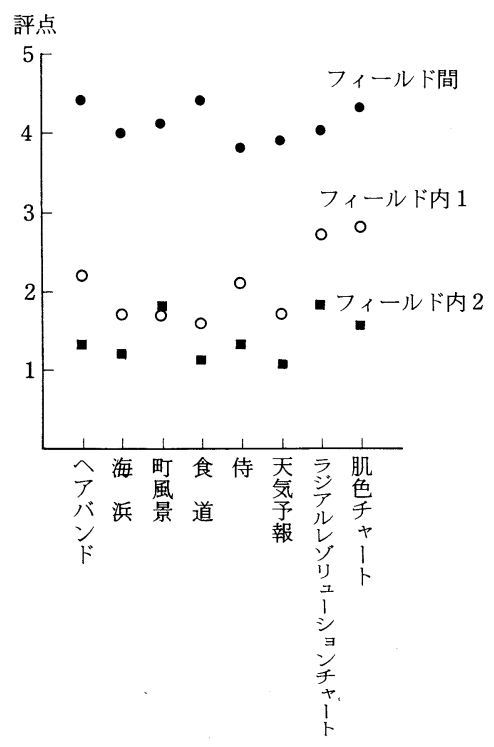

図 6 メディアンフィルタによる歪みの発生の評価值6) Subjective evaluation for the blurry effect of dedicated kernels.
実用的でないのに比べ, 図 1 ( a ) のカーネルは, いず れの画像についても歪みの発生はほぼ検知限前後にあ ることがわかる。この結果と, 図 5 による雑音除去効 果の評価とを併せて考えた場合, 図 1 ( a ) が最適の力 ーネルであると結論づけられる.

\section{2 信号の処理形態に関する考察}

テレビ信号の処理形態には，コンポジット信号のま ま処理を行うコンポジット信号処理と, 一度コンポー ネント信号にデコードしてから処理を行うコンポーネ ント信号処理がある.メディアンフィルタのような非 線形操作を施す際には，信号の処理形態の違いによる 影響の有無を確認しておくことも重要である．図７に ITEテストチャート（肌色チャート）を信号源 Bとし て入力し, コンポジット信号処理と, RGB コンポー ネント信号処理を行った場合の雑音除去効果の評価結 果を示す．この場合のカーネルは，コンポジット信号 に対しては図 1(a)，コンポーネント信号に対して は, 図 8 に示すものとした (いずれも $W=3$ ). 図 7 か ら，入力信号の形状をコンポジット信号としてもコン ポーネント信号としても雑音除去効果の評価值にはほ とんど差がなく, どちらも 3 章での考察から導かれた 理論值とよく一致していることがわかる．また，いず れの場合にも歪みの発生はほとんど検知されなかっ た．このことから, 双方の方式で出力画像においてほ ぼ同一の効果を得ることができるが, コンポジット信 号のまま処理する方が, コンポーネント信号を処理す る場合に比べ, フィルタの回路規模の面から見て有利 であるといえる，写真 1 に，図 1 (a)のカーネルを用 いてコンポジット信号中の雑音除去を行った場合の入 出力画像の例を示す.

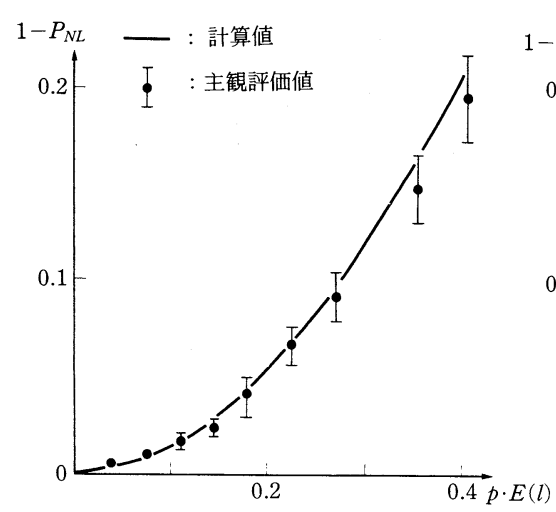

(a) NTSC コンポジット信号入力 $(l=10)$

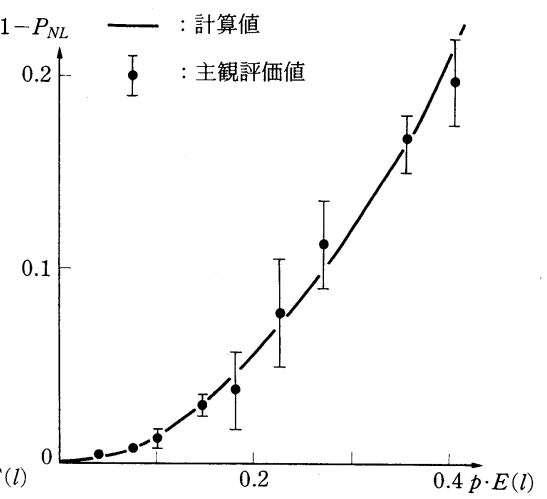

(b) RGB コンポーネント信号入力 $(l=10)$

図 7 雑音除去効果の計算值と主観評価結果との比較 $(l=10)$ Comparison between the results of calculation and subjective evaluation on the noise elimination.

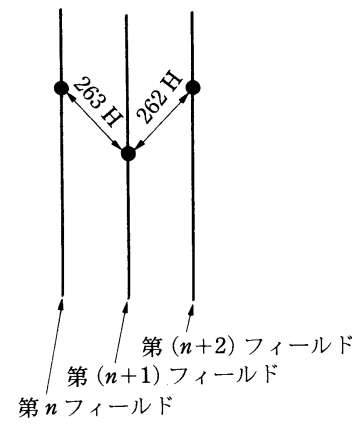

図 8 コンポーネント信号に対 するカーネル構造の例

Examples of the Kernel structure for TV component signals. 


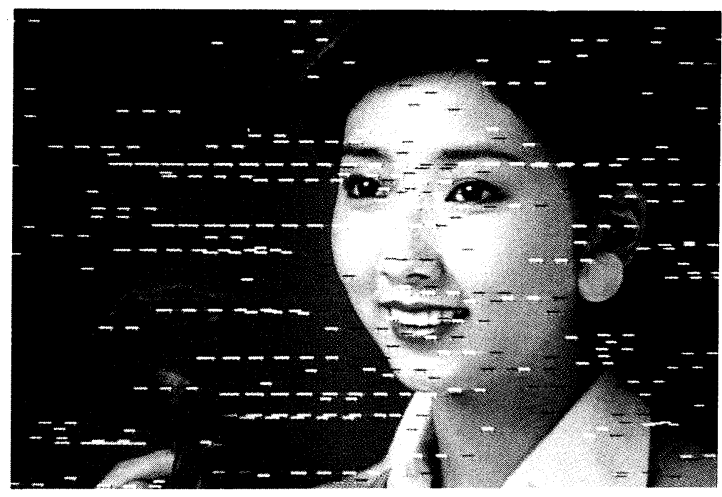

(a) 入力画像

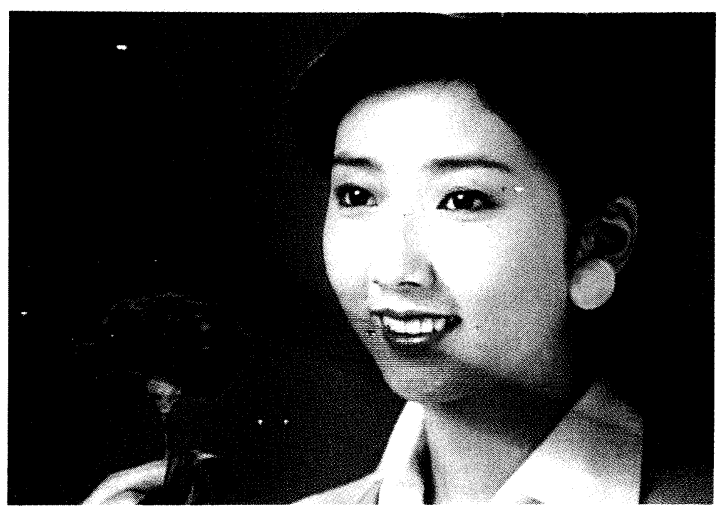

(b) 処理画像

写真 1 雑音除去処理画像の例

(テストパターン : $p=0.014, p_{w}=0.5$ )

Images obtained by the noise elimination system using the Rank-Order filter. (Test pattern : $p=$ $0.014, p_{w}=0.5$ )

(a) Input image, (b) output image.

\section{3 動画像への適用に関する検討}

以上の議論では, フィルタの構成として複数のフィ ールドにまたがったカーネルを用いるなど, 静止画像 または動き領域がほとんど含まれない画像を仮定して 考察を進めてきた。これに対しテレビ画像は多くの動 き領域を含んでいる。動き領域で図 1 (a) や図 8 に示 すようなカーネルを用いた場合, カーネル内画素の輝 度信㰾や色信号の相関が低くなり，新たに歪みを発生 することがある。

しかし現段階では, この種のフィル夕の適用範囲 を, フィルタによる動き領域での画像の変形(歪み)を ある程度許容してもなお , 雑音除去の効果が著しく高 いと判定される画像に限ることを前提として考察する ことが現実的であると考え, 本論文で提案するフィル 夕構成を, インパルス性雑音が最も劣悪な画質阻害要 因となっている動画像に対してそのまま適用した場合

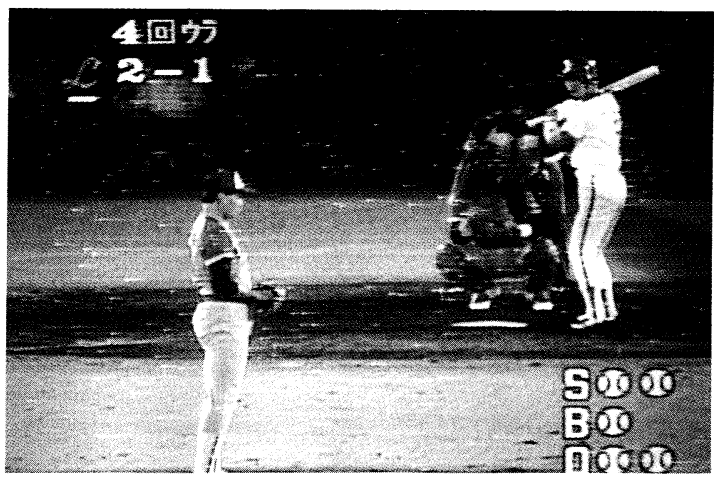

(a) 入力画像

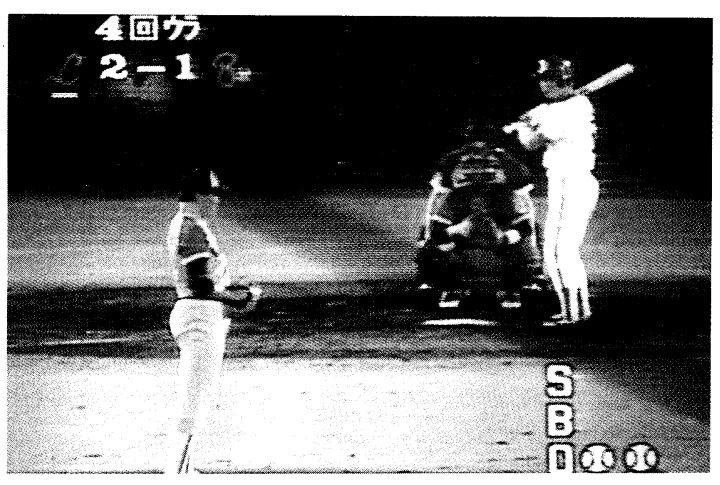

(b) 処理画像

写真 2 雑音除去処理画像の例(BS 受信像) Images obtained by the noise elimination system using the Rank-Order filter. (Image through BS tunner)

(a) Input image, (b) output image.

の効果と問題点を確認することとした．動画像には信 号源 A を用い, 一般画像 (BS 受信画像) に対する処理 結果を著者らが観察し, その効果と歪みによる劣化の 程度を以下に示すように定性的に評価した。

まず, 雑音除去の効果については, 動きを含む画像 を処理した場合にも，静止画像の場合と同様，充分な 効果があり，入力信号の形式（コンポジット信号かコ ンポーネント信号か)にはほとんど依存しなかった。 また動き領域において, 図 1（a）のようなカーネルが お互いに相関の低い画素を選択してしまうことによる 歪みの視覚的な影響については, この種のフィルタで は動きのある物体とその背景との信号レベルの順序関 係で出力が決まるため, すべての動領域で信号の劣化 が発生するということはなく, 特にアニメや, 映画等 のフィルム素材に関してはほとんど劣化の発生は認め られないことがわかった。一方，ビデオ素材に関して 
は，縦方向の高域信号 (横縞) 部分 (人物の目や, 眼鏡 のフレーム, バスケットコートに引かれた白線など） の上下動の際に劣化が発生する場合があった。しか し, このような歪みの発生しやすい領域がかなり頻繁 に現れるスポーツ中継のような番組においても, 雑音 が頻繁に発生している場合には, 雑音の除去効果の方 が大きいと判断できることがわかった。

写真 2 には, 一般画像に対する処理の例として, BS 受信画像 (信号源 A) 中に現れるめだか状雑音の除 去例を示す.

上に述べたように動画像に対しては，もはや図 1 ( a )に示す単純なカーネルが最適であるとは限らな い.この場合の対策としては, 例えば，(1)静止領域と 動き領域において図 1（a）と図 1（b)のカーネルを適 応的に切り替えて用いる，(2)画素単位での動きべクト ルが決定できるならば，これを参照しつつ常に信号と して相関の高い画素が選択できるよう，カーネル形状 を適応的に変化させる，などの手法が必要となる，こ れは今後の課題と考えるが, 一方, (1)処理装置として の完成度追求は，回路規模の増大につながり易く，比 較的簡易な装置による効果的な処理の実現という，こ の種のフィルタの本来目的とは相反してくること, (2) 動画像処理における画質評価法が充分に確立していな いこと，などから，回路方式等については充分な検討 が必要となろう。

\section{6. む す び}

ランクオーダフィルタをカラーテレビ信号中の雑音 除去に適用する実験を行った。その結果，コンポジッ ト信号に適合させたカーネルを用いることにより，比 軸的小さなハードウェアで効果的に適用できることを 確認した。また, 雑音除去効果に対する主観的評価手 法について検討し，これによる評価結果が我々の理論 的検討から予測される值とよく一致することを確認し た.一方で, フィルタリングによって動き領域に発生 する歪みの定量化や，これを低減するためのフィル夕 構成に関する議論は行わなかった。これについては, 今後のテレビ画像処理における動画像評価法の進展に 合わせて, さらに充分な検討を続けて行く必要があ る.

最後に, 本研究の機会を与えて頂いた当所杉本所 長, 吉川次長, ならびに有益な助言を頂いた川島部長 に深謝します。また，実験に用いたLSIの試作に協
力して頂いた渡辺，田島，後藤，大町，大竹氏に感謝 します。

\section{〔参 考 文 献〕}

1) T. A. Nodds and N. C. Gallagher, Jr.: "Median Filters; some Modifications and Their Properties", IEEE, Trans. Acoust., Speech \& Signal Process., ASSP-30, 5, pp. 739746 (1982)

2) 小林(和)：“ランクオーダフィルタのインパルス性雑音の除 去特性に関する考察”, 信学論誌 A, J73-A, 4, pp. 741-749 (1990)

3）小林(和)，国分，明智，小林(希)：“映像信号用リアルタイ 厶順序フィルタ LSI”, 昭 63 年度信学秋全大予, C-116 (1988)

4）小林(和), 国分, 明智, 阿部, 田島, 大町: “映像信号リア ルタイム順序フィルタ LSI とそのノイズ除去への応用”, 平 成元年度信学秋全大予, C-130（1989）

5）小林(和)，国分, 明智, 田島, 大男, 阿部, 小林(希)：“画 像用非線形ディジタルフィルタ LSI”, NHK 技研 R\&D, No. 7 (1989)

6）小林(和)，山本，国分，明智，阿部：“メディアンフィル夕 を用いたテレビ信号中の雑音除去”, 平成 2 年度信学春全大 予稿，D-270 (1990)

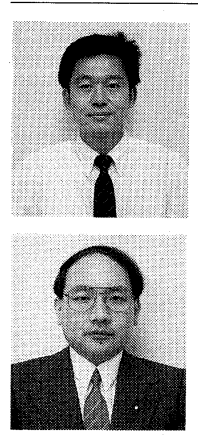

小林架和正 昭和 57 年, 東京工業大学大 学院電子システム専攻修士課程修了. 同年, NHK に入局. 京都放送局を経て，60 年よ り, 同放送技術研究所に勤務. 画像処理用 LSI の研究開発に従事. 正会員.

国篎㑧樹 昭和 49 年, 東京工業大学工 学部電気工学科卒業. 同年, NHK 亿入局. 室蘭放送局を経て, 53 年より，同放送技術 研究所に勤務. 半導体デバイスの設計開発, 特にテレビ映像信号の高速ディジタル信号処 理用 VLSI の研究開発に従事. 正会員.

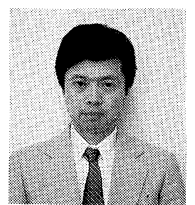

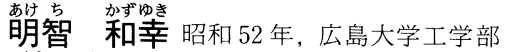
電気工学科卒業. 同年, NHK に入局. 松山 放送局を経て，現在，同放送技術研究所に勤 務. 画像処理 LSI の研究に従事. 正会員.

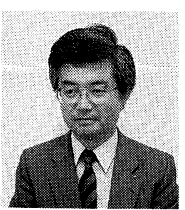

覀部 正英 昭和 44 年, 東京大学工学部 電子工学科卒業. 同年, NHK に入局. 宮崎 放送局を経て, 51 年上り, 同放送技術研究 所に勤務. 現在, 同所特性素子研究部主任研 究員.八イビジョン用LSI, 画像処理用 LSI, 固体撮像素子等テレビ信号処理デバイ スの研究・開発に従事。正会員

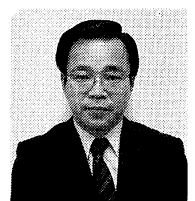

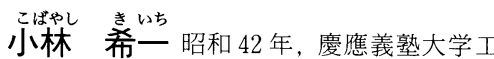
学部電気工学科大学院修士課程修了. 同年, NHKに入局．札幌中央放送局を経て，45 年より, 同放送技術研究所に勤務. 光電変換 デバイス，MOSトランジスタテレビ信号 処理用 MOS 論理 LSI 等の研究に従事. 現 在, 同所物性素子研究部副部長. 正会員. 


\title{
アバランシェ増倍 $a$-Se 光導電膜を用いた高感度 HARP 撮像管
}

\author{
谷岡健吉, 山崎順一, 設楽圭一, 竹歳和久, 河村達郎,
} 平井忠明，高崎幸男，雲内高明

アモルファス Se $(a-\mathrm{Se})$ を主成分とする光導電ターゲットを強い電界で動作させると, アバラン シェ（なだれ）増倍作用により，極めて高い感度が得られることを見出したａ-Seターゲットに $240 \mathrm{~V}$ の電圧を印加した場合, 青色光 (B 光) に対する量子効率 (単位入射光子数当たりの出力電子 数, 以下 $\eta)$ が 10 となり, 従来の阻止型ターゲットを用いた光導電型撮像管の感度の理論限界 $(\eta$ =1）をはるかに上回る高い感度が得られた。このときの暗電流は $0.2 \mathrm{nA}$ と小さかった．また，ア バランシェ増倍に伴う残像, 解像度等の特性劣化は認められなかった。試作管を実装したカラーカ メラでは, 被写体照度 $180 \mathrm{~lx}$, レンズ絞り F 4 の条件で, 従来のスタジオカメラの標準撮像時 (2000 lx，F 4) とほほ同等の良好な画像が得られた。

テレビジョン学会誌 Vol. 44, No. 8, pp. 1074〜1083（1990）

\section{動物体領域に着目したテレビ信号の動き検出}

平野裕弘, 石倉和夫

IDTV, EDTV の動き適応型信号処理に適用するため, 画像の物体領域に着目したテレビ信号 の動き情報検出方式について検討を行った。

この方式は，画像のパターン部を 1 個の物体領域として抽出し，フレーム間の演算で得られる差 分信号から物体領域の動きの有無を判定する。そして, 動きと判定した動物体領域では差分信号の 絶対値の最大值を動きの情報として選ぶことにより, 検出漏れの少ない動き検出を実現する.

順次走査変換のための走査線補間にこの方式を適用し, 従来方式に較べて検出漏れの発生が少な いこと, 時空間積分に伴なった画像の不自然さが低隇できることを確認した。そして, 動きの検出 精度の向上, 画質の改善に有効なことを示した.

テレビジョン学会誌 Vol. 44, No. 8, pp. 1084〜1089（1990）

\section{ランクオーダフィルタによるカラーテレビ信号中の インパルス性雑音の除去}

小林和正，国分秀樹，明智和幸，阿部正英，小林希一

本論文では, カラーテレビ信号中に混入するインパルス性雑音の除去法と, 雑音除去効果の定量 化の手法について検討する. 具体的には, (1) カラーテレビ信号の処理にランクオーダフィルタを 適用する場合のカーネル形状, (2) 雑音除去特性の客観的解析手法, (3) 雑音除去効果の主観評価実 験手法，の提案を行うとともに，上記提案に基づいて構成したフィル夕による雑音除去効果の評価 実験について報告する。

実験の結果, (1) 静止画像に対しては 3 フィールドにわたってカラーサブキャリヤの位相が揃う 画素を取出して処理するカーネルが最も効果的であること, (2) 提案した主観評価実験結果と理論 検討から予想される值とがよく一致すること, などがわかり, 本論文で提案する雑音除去法のテレ ビ信号処理における有効性が明らかとなった。 